\title{
Kajian inovasi pemanfaatan hasil ikutan tanaman sawit untuk meningkatkan produksi sapi lokal di Kabupaten Aceh Tamiang
}

\author{
Yenni Yusriani ${ }^{1,}$ *, Mustafa Sabri ${ }^{2}$, Nur Inda Rahayu ${ }^{3}$, Endang Tri Rahayu ${ }^{4}$, Elviwirda ${ }^{1}$, Rini \\ Adriani ${ }^{1}$ \\ ${ }^{1}$ Balai Pengkajian Teknologi Pertanian (BPTP), Aceh, 23125 \\ ${ }^{2}$ Fakultas Kedokteran Hewan, Universitas Syiah Kuala, Aceh, 23111 \\ 3Sekolah Menengah Kejuruan (SMK) Negeri 1 Kedawung, Sragen, 57292 \\ ${ }^{4}$ Program Studi Peternakan, Fakultas Pertanian, Universitas Sebelas Maret, Surakarta, 57126 \\ *Correspondence: yenniyusrani@ymail.com
}

Received: December 26 ${ }^{\text {th }}$, 2020; Accepted: May 14 ${ }^{\text {th }}, 2020$; Published online: July 17 ${ }^{\text {th }}, 2020$

Abstrak

Tujuan: Kajian tentang inovasi pemanfaatan hasil ikutan sawit bertujuan untuk meningkatkan produksi sapi lokal di Kabupaten Aceh Tamiang.

Metode: Sapi yang digunakan sebanyak 15 ekor sapi jantan untuk penggemukan dengan tiga perlakuan, yakni: P1 = Rumput lokal $70 \%+$ konsentrat 30\%, P2 = Silase jagung 35\% + silase pelepah sawit 35\% + indigofera 30\% dan P3 = Silase jagung 40\% + silase pelepah sawit 30\% + indigofera 30\%. Pengamatan dilakukan selama 4 bulan dengan masa adaptasi 2 minggu. Teknik pengambilan sampel responden dilakukan sebanyak 20 orang peternak melalui metode survei dan kuesioner. Data dikumpulkan, meliputi: koordinasi dengan dinas terkait, karakteristik peternak, aspek pemberian pakan serta layanan peternakan, pertambahan berat badan harian dan penerimaan selama kajian berlangsung. Data yang dikumpulkan diolah secara tabulasi dan dianalisis secara diskriptif.

Hasil: Hasil kajian menunjukkan bahwa pemberian pakan mengandung hasil ikutan sawit dapat menaikan berat badan sapi 0,31 (P3) dan 0,34 (P2) kg/ekor/hari, sedangkan kenaikan berat badan pada ternak kontrol hanya sebesar 0,21 (P1) kg/ekor/hari. Penerimaan peternak selama kajian berlangsung adalah sebesar Rp12.320.000 (P1), Rp12.950.000 (P2) dan Rp13.140.000 (P3), hasil penerimaan tertinggi terdapat pada perlakuan P3 karena pertambahan berat badan pada perlakuan P3 sedikit lebih tinggi sehingga berpengaruh langsung terhadap harga jual ternak.

Kesimpulan: Hasil analisis data membuktikan bahwa pemberian pakan mengandung hasil ikutan sawit mampu meningkatkan produksi sapi lokal di Kabupaten Aceh Tamiang.

Kata Kunci

Abstract

Objective: The study of innovative use of palm oil by products aims to increase local bulls production in Aceh Tamiang District.

Methods: Fifty five bulls were used in the current experiment that were allocated into three different treatments with five bulls in every treatment. The treatments were: $\mathrm{P} 1=70 \%$ native grass $+30 \%$ 
concentrate, $\mathrm{P} 2=35 \%$ corn silage $+35 \%$ palm frond silage $+30 \%$ Indigofera and $\mathrm{P} 3=40 \%$ corn silage $+30 \%$ palm frond silage $+30 \%$ Indigofera. Observation was carried out for 4 months with an adaptation period was 2 weeks. During survey, twenty respondents were interviewed using questionanaire. The data collections includ: a coordination with relevant agencies, characteristics of farmers, aspects of feeding and livestock services, daily liveweight gain and cash income during the study. The data collected was tabulated and analyzed descriptively.

Results: The results of the study showed that the use of palm oil by product resulted the liveweight gain of bulls 0.31 (P3) and 0.34 (P2) kg/head/day, whereas control bulls 0.21 (P1) kg/head/day with cash income were Rp12,320,000 (P1), Rp12,950,000 (P2) and Rp13,140,000 (P3), whereas the highest income was in the $\mathrm{P} 3$ because the liveweight was slightly higher so that it directly affected the selling price of livestock.

Conclusions: The results of the analysis of the data prove that feeding containing the by-product of oil palm can increase local cattle production in Aceh Tamiang Regency.

Keywords: Breeder profile, Feeding management, Liveweight gain

\section{PENDAHULUAN}

Sebagai salah satu subsektor pertanian, peternakan berperan penting dalam penyediaan bahan pangan, terutama dalam pemenuhan protein hewani bagi masyarakat [1]. Di Aceh, ternak besar seperti sapi potong mempunyai peranan yang sangat penting dalam kehidupan masyarakatnya. Karena peternak telah biasa memelihara ternak sebagai tenaga pengolah sawah, lapangan kerja, tabungan dan memiliki nilai sosial [2]. Priyanto [3], menyatakan bahwa kebutuhan akan daging sapi di Indonesia menunjukkan trend yang meningkat setiap tahunnya, demikian pula laju impor daging sapi terus meningkat.

Salah satu bentuk usaha peternakan yang cukup potensial dikembangkan adalah ternak sapi potong [4]. Produk utama dari sapi potong berupa daging sapi. Daging sapi merupakan salah satu pangan strategis dari hasil peternakan yang menjadi target swasembada. Namun, produksinya masih belum dapat memenuhi kebutuhan dalam negeri, dimana neraca kebutuhan dan ketersediaan daging sapi di tahun 2012 mengalami defisit produksi sebesar 21.46-28.06 persen [5].

Produktivitas usaha ternak masih rendah. Hal ini terjadi karena pola manajemen pemeliharaan ternak yang kurang terarah, dimana peternak belum optimal memperhatikan kualitas pakan, tata cara pemeliharaan yang dianjurkan, perkandangan, penanganan penyakit dan pemasaran [6]. Pemasaran ternak khususnya sapi potong sampai saat ini cukup sederhana. Jalur yang dilewati dari peternak ke tangan konsumen masih relatif panjang, selain itu peran pedagang dan blantik yang masih besar dalam jual beli ternak akan menyebabkan harga yang diterima peternak menjadi kecil. Strategi pemasaran perlu dilakukan agar dapat melaksanakan pemasaran yang efisien, karena dengan pemasaran yang efisien dapat memotivasi peternak dalam meningkatkan usaha, sehingga produktivitas dapat ditingkatkan. Kualitas sumber daya manusia akan membantu pola peternakan yang akan terbentuk. Pendidikan, pengalaman, umur, dan pengetahuan yang baik dari peternak akan membawa usaha menuju kearah yang baik dengan menerima inovasi teknologi yang diberikan. Faktor pendorong pengembangan sapi potong disebabkan permintaan pasar terhadap daging sapi makin meningkat, ketersediaan tenaga kerja yang cukup besar, adanya kebijakan pemerintah yang mendukung upaya pengembangan sapi potong, hijauan pakan dan limbah pertanian yang tersedia sepanjang tahun, dan usaha peternakan sapi lokal tidak terpengaruh oleh krisis ekonomi global [8].

Dampak perubahan dari sistem pemeliharaan yang baik antara lain terlaksananya proses mulai dari pemilihan atau seleksi bibit unggul, sistim perkandangan yang bersih dan memiliki drainase yang baik serta pemilihan pakan yang murah namun tetap memperhatikan status gizi [9]. Oleh karena itu, produktivitas 
usaha ternak sapi potong serta karakteristik peternak dengan memanfaatkan hasil ikutan tanaman sawit untuk meningkatkan produksi sapi lokal di kabupaten Aceh Tamiang menjadi menarik untuk diteliti. Berbagai penelitian juga menunjukkan bahwa pemanfaatan hasil samping sawit untuk pakan ternak sapi mempunyai prospek yang menjanjikan untuk mendukung pengembangan sapi potong di masa mendatang $[10,11]$.

\section{MATERI DAN METODE}

\section{Waktu dan tempat Penelitian}

Pelaksanaan kajian berlangsung pada bulan April - Agustus 2018, di Kecamatan Karang Baru Kabupaten Aceh Tamiang.

\section{Penentuan lokasi dan sampel penelitian}

Penentuan lokasi kajian dilakukan melalui koordinasi dengan dinas terkait dengan pertimbangan bahwa di Kecamatan Karang Baru terdapat peternak sapi lokal. Penentuan responden sebagai obyek sebanyak 20 responden. Obyek penelitian adalah peternak yang memelihara sapi dengan kriteria usaha minimal 1 ekor induk yang sudah pernah melahirkan atau 1 ekor jantan umur $\geq 2$ tahun dan yang memiliki pengalaman beternak sapi minimal 1 tahun. Materi yang digunakan adalah 15 ekor sapi jantan lokal untuk penggemukan, pelepah sawit, jagung, konsentrat dan indigofera.

\section{Teknik pengumpulan data}

Tahapan yang dilakukan pertama kali yaitu koordinasi dengan dinas terkait untuk menetapkan calon petani dan calon lokasi (CPCL) agar kajian berjalan sesuai dengan tujuan dan iuaran yang diharapkan dari kegiatan. Kemudian kegiatan survei profil peternak dan aspek pemberian pakan serta layanan peternakan dilakukan pada usaha sapi potong pada masyarakat di sekitar lokasi sentra tanaman sawit. Survei ini menggali informasi profil peternak dan aspek pemberian pakan serta layanan peternakan di lokasi kegiatan. Kelompok tani terpilih

Tabel 1. Karakteristik peternak di lokasi kegiatan

\begin{tabular}{|c|c|c|c|}
\hline No & Profil peternak & Jumlah orang $(n=20)$ & Persentase $(\%)$ \\
\hline \multirow[t]{4}{*}{1} & Umur & & \\
\hline & a. 31- 40 tahun & 16 & 80 \\
\hline & b. $41-50$ tahun & 2 & 10 \\
\hline & c. $>51$ tahun & 2 & 10 \\
\hline \multirow[t]{3}{*}{2} & Jenis kelamin & & \\
\hline & a. Laki-laki & 20 & 100 \\
\hline & b. Perempuan & 0 & 0 \\
\hline \multirow[t]{4}{*}{3} & Pendidikan & & \\
\hline & a. SD & 0 & 0 \\
\hline & b. SMP & 4 & 20 \\
\hline & c. SMA & 16 & 80 \\
\hline \multirow[t]{3}{*}{4} & Pekerjaan & & \\
\hline & a. Pokok & 14 & 70 \\
\hline & b. Sambilan & 6 & 30 \\
\hline \multirow[t]{4}{*}{5} & Pengalaman beternak & & \\
\hline & a. $<5$ tahun & 2 & 10 \\
\hline & b. 5-25 tahun & 18 & 90 \\
\hline & c. $>25$ tahun & 0 & 0 \\
\hline
\end{tabular}

Sumber: Data primer diolah, 2018. 
dikoordinasikan dengan dinas pertanian dan peternakan kabupaten Aceh Tamiang, yang diseleksi sesuai kriteria: bersedia bekerjasama dan mau menerapkan teknologi pemanfaatan hasil ikutan tanaman sawit.

Kajian teknologi pemanfaatan pakan hasil ikutan tanaman sawit terdiri dari pemberian silase pelepah sawit, silase jagung dan indigofera pada sapi potong. Pakan berbasis tanaman sawit diberikan pada sapi lokal. Ternak dipelihara dalam sistem yang semi intensif. Sapi yang digunakan sebanyak 15 ekor sapi jantan untuk penggemukan. Kajian ini telah mendapatkan registerasi etik dengan nomor:

Balitbangtan/BPTPAceh/Rm/01/2019. Ada tiga perlakuan pakan yang diberikan, yaitu:

$\mathrm{P} 1=$ Rumput lokal $70 \%+$ konsentrat $30 \%$,

P2 = Silase jagung $35 \%$ + silase pelepah sawit $35 \%+$ indigofera $30 \%$ dan

P3 = Silase jagung $40 \%$ + silase pelepah sawit $30 \%+$ indigofera $30 \%$.

Pemberian pakan dilakukan 2 kali sehari yaitu pada pagi hari pukul 08:00 WIB dan pada sore hari pukul 17:00 WIB sedangkan air minum diberikan ad-libitum. Pengamatan dilakukan selama 4 bulan dengan masa adaptasi 2 minggu.

\section{Variabel yang diamati}

Variabel yang diamati meliputi: koordinasi dengan dinas pertanian dan peternakan kabupaten Aceh Tamiang,

Tabel 2. Aspek pemberian pakan serta layanan peternakan

\begin{tabular}{|c|c|c|c|}
\hline No & Komponen & Jumlah Orang $(n=20)$ & Persentase $(\%)$ \\
\hline \multirow[t]{4}{*}{1} & Sistem pemeliharaan ternak & & \\
\hline & a. Dikandangkan (Intensif) & 0 & 0 \\
\hline & $\begin{array}{l}\text { b. Digembalakan pada pagi hari dan sore hari } \\
\text { dikandangkan (Semi intensif) }\end{array}$ & 20 & 100 \\
\hline & c. Digembalakan sepanjang hari (extensif) & 0 & 0 \\
\hline \multirow[t]{17}{*}{2} & Pakan (\%) & & \\
\hline & Hijauan & & \\
\hline & a. Diberikan & 20 & 100 \\
\hline & b. Tidak & 0 & 0 \\
\hline & Konsentrat & & \\
\hline & a. Diberikan & 20 & 100 \\
\hline & b. Tidak & 0 & 0 \\
\hline & Suplemen Mineral & & \\
\hline & a. Diberikan & 20 & 0 \\
\hline & b. Tidak & 0 & 100 \\
\hline & Sistem Pemberian Pakan & & \\
\hline & a. Merumput di sawah & 0 & 0 \\
\hline & b. Merumput di umbaran & 2 & 10 \\
\hline & c. Merumput di umbaran dan diberi rumput & 18 & 90 \\
\hline & Ketersediaan HPT: & & \\
\hline & a. Banyak & 20 & 100 \\
\hline & b. Kurang & 0 & 0 \\
\hline 3 & Pelayanan Inseminasi Buatan (IB) & 20 & 100 \\
\hline 4 & Pelatihan Teknis & 20 & 100 \\
\hline
\end{tabular}

Sumber: Data primer diolah, 2018 
karakteristik peternak, aspek pemberian pakan serta layanan peternakan oleh dinas peternakan kabupaten Aceh Tamiang, pertambahan berat badan harian dan penerimaan selama kajian berlangsung.

\section{Analisis data}

Data yang dikumpulkan ditabulasi dan dianalisis secara diskriptif.

\section{HASIL}

\section{Kondisi geografis dan agrofisik wilayah}

Kabupaten Aceh Tamiang merupakan salah satu wilayah administrasi Propinsi Aceh berada pada posisi geografis 04 $32^{\prime} 56,76^{\prime \prime}$ Lintang Utara dan 98 $14^{\prime} 45,41^{\prime \prime}$ Bujur Timur dengan batas aministrasi; (a) sebelah Utara dengan Kabupaten Aceh Timur, Kota Langsa dan Selat Malaka, (b) sebelah Selatan dengan kabupaten Langkat Propinsi Sumatera Utara dan Kabupaten Gayo Lues, (c) sebelah Timur dengan Kabupaten Langkat Propinsi Sumatera Utara dan Selat Malaka, dan (d) sebelah Barat dengan Kabupaten Aceh Timur dan Gayo Lues. Kabupaten Aceh Tamiang mempunyai luas wilayah 1957,02 km² dengan ibukotanya Karang Baru meliputi 12 kecamatan dan 213 desa. Letak kabupaten Aceh Tamiang yang berbatasan langsung dengan ibukota propinsi Sumatera Utara menjadikannya sebagai pintu gerbang utama dan berpeluang tumbuh serta berinteraksi dengan wilayah kabupaten lain dan menjadikan mobilitas barang dan jasa termasuk hasil produksi pertanian dan peternakan cukup tinggi.

Variabel yang akan diamati dalam kajian inovasi pemanfaatan hasil ikutan tanaman sawit meliputi:

\section{Koordinasi dengan instansi terkait}

Pelaksanan koordinasi dengan Dinas terkait dalam penentuan lokasi kegiatan dilaksanakan pada kabupaten melibatkan Dinas Pertanian dan Kesehatan Hewan
Kabupaten Aceh Tamiang. Pada saat koordinasi dijelaskan tentang; rencana kegiatan penelitian, pentingnya kesepakatan calon lokasi, dan evaluasi calon lokasi. Sehingga dapat dipilih lokasi dan kelompok ternak yang sesuai dengan permasalahan penelitian ini di lapangan. Pemilihan lokasi dan kelompok ternak mengacu kepada tujuan dan sasaran kajian. Kriteria pemilihan kelompok sesuai dengan tujuan dan sasaran yang meliputi: meningkatnya produktivitas sapi lokal (melalui kajian inovasi pakan dari hasil ikutan tanaman sawit) serta meningkatkan pengetahuan dan pemahaman peternak terhadap teknologi inovasi yang diberikan.

Selanjutnya dilakukan pengamatan terhadap kelompok dan anggotanya dengan syarat sebagai berikut: peternak mempunyai pengalaman dalam beternak sapi dan peternak terpilih mempunyai kemauan dan kerjasama untuk melakukan kajian. Berdasarkan usulan dari Dinas terkait dengan pertimbangan keunggulan dan kelemahan tiap lokasi maka pilihan terbaik adalah Kelompok Maju Bersama, karena dianggap kelompok sangat antusias menerapkan teknologi baru, khususnya untuk membuat pemanfaatan hasil ikutan sawit.

\section{Kegiatan survei profil peternak dan aspek pemberian pakan serta layanan peternakan}

Survei dilakukan pada usaha sapi potong milik masyarakat di sekitar lokasi sentra tanaman sawit. Survei ini menggali informasi profil peternak dan aspek pemberian pakan yang selama ini dilakukan oleh peternak serta layanan peternakan di lokasi kegiatan meliputi pemeriksaan kesehatan, pemeriksaan kebuntingan dan inseminasi buatan. Pengumpulan data kuesioner berdasarkan Bamualim et al. [12] sebagai berikut: kuesioner disiapkan sebelum ke lapangan sebanyak 20 responden, sesuai kesepakatan tempat dan waktunya anggota kelompok berkumpul di lokasi kandang 
koloni sapi untuk pengisian kuesioner, tiap peternak mengisi sendiri kuesioner dengan ketentuan bahwa apabila ada sesuatu hal yang perlu dijelaskan maka salah satu anggota tim kajian memberikan pengertian tentang maksud soal tersebut, salah seorang anggota tim khusus mewawancarai ketua kelompok tentang profil kelompok secara keseluruhan, setelah semua anggota selesai mengisi kuesioner maka diskusi diteruskan dengan rencana tindak lanjut persiapan penyelenggaraan kajian.

\section{Karakteristik peternak di lokasi kegiatan}

Kemampuan peternak dalam mengelola sangat menentukan tingkat keberhasilan usaha peternakan. Untuk mengetahui kemampuan peternak perlu diketahui latar belakang yang berhubungan dengan keterlibatan mereka dalam mengusahakan ternaknya. Pertimbangan yang digunakan untuk meliputi umur peternak, jenis kelamin, tingkat pendidikan, pekerjaan serta pengalaman peternak. Data karakteristik peternak tersebut disajikan lengkap pada Tabel 1.

Berdasarkan Tabel 1, pendidikan sangat berkaitan dengan kemampuan seseorang dalam memahami sesuatu, dimana dengan memiliki pengetahuan formal yang lebih tinggi maka seseorang akan memiliki motivasi lebih tinggi. Tingkat pendidikan peternak relatif beragam, dengan didominasi oleh tingkat SMA $(80 \%)$, sedangkan tingkat terendah SMP $20 \%$.

Aspek pemberian pakan serta layanan peternakan oleh Dinas Peternakan Kabupaten Aceh Tamiang

Keseluruhan hasil dari kajian mengenai aspek pemberian pakan serta layanan peternakan dapat dilihat pada Tabel 2.

\section{Pertambahan bobot badan harian (PBBH)}

Bobot hidup awal, bobot hidup akhir, kenaikkan bobot hidup, PBBH selama perlakuan dapat dilihat pada Tabel 3 . Pertambahan bobot badan sapi diperoleh dari hasil penimbangan bobot badan akhir dikurangi dengan bobot awal dalam satuan g/ekor/hari. Sistem pemeliharaan ternak semi intensif merupakan sistem pemeliharaan sapi potong dengan sebagian pemeliharaannya digembalakan dan sebagian lagi dikandangkan. Sistem pemeliharaan yang dilaksanakan peternak tidak lepas dari kondisi sosial ekonomi peternak. Jika dilakukan sistem pemeliharaan semi intensif, maka pakan yang baik secara kualitas harus disiapkan untuk ternak saat dikandangkan pada saat malam hari untuk memenuhi kebutuhan nutrisinya [13]. Pada Tabel 3 memperlihatkan bahwa terdapat perbedaan pertambahan berat badan ternak antar perlakuan.

\section{Penerimaan}

Penerimaan adalah nilai produksi yang dihasilkan dari suatu usaha, makin besar produk yang dihasilkan maka semakin besar pula penerimaannya, dan begitu pula sebaliknya, akan tetapi penerimaan yang besar belum tentu menjamin pendapatan

Tabel 3. Rataan bobot hidup awal, bobot hidup akhir, kenaikkan bobot hidup, PBBH selama 3 bulan perlakuan

\begin{tabular}{ccccc}
\hline \multirow{2}{*}{ Perlakuan } & Bobot hidup awal & Bobot hidup akhir & Kenaikan bobot hidup & PBBH \\
& $(\mathrm{kg})$ & $(\mathrm{kg})$ & $(\mathrm{kg})$ & $(\mathrm{kg})$ \\
\hline P1 & 221 & 246,4 & 25,4 & $0,21^{\mathrm{a}}$ \\
P2 & 218 & 259 & 41 & $0,34^{\mathrm{b}}$ \\
P3 & 226 & 262,8 & 36,8 & $0,31^{\mathrm{b}}$ \\
\hline
\end{tabular}

P1, rumput lokal $70 \%+$ konsentrat 30\%; P2, silase jagung 35\% + silase pelepah sawit 35\% + indigofera 30\%; P3, silase jagung 40\% + silase pelepah sawit $30 \%$ + indigofera $30 \%$.

ab angka yang diikuti oleh huruf yang sama menunjukkan tidak berbeda nyata $(\mathrm{p}<0.05)$. 
yang besar [14] diukur dalam satuan rupiah per tahun [15]. Hasil penerimaan pada penelitian ini dihitung dari $\mathrm{kg}$ berat badan akhir ternak dikalikan dengan harga per kilogram berat hidup. Tabel 4 menunjukkan bahwa hasil penerimaan tertinggi terdapat pada perlakuan P3 yaitu sebesar Rp13.140.000. Hal ini disebabkan karena pertambahan berat badan pada perlakuan P3 sedikit lebih tinggi dari perlakuan yang lain, sehingga berpengaruh langsung terhadap harga jual ternak. Semakin tinggi kemampuan atau kompetensi kewirausahaan seseorang, maka akan semakin meningkatkan produktivitas usaha yang dilakukan dari segi penerimaan [16].

\section{PEMBAHASAN}

Karakteristik adalah sifat-sifat yang ditampilkan oleh seseorang yang berhubungan dengan semua aspek kehidupan dalam lingkungannya sendiri. Chamdi [17], menyatakan bahwa semakin muda usia peternak (usia produktif 31-40 tahun) umumnya rasa keingintahuan terhadap sesuatu dan introduksi teknologi semakin tinggi. Sebagian besar $(\geq 80 \%$ responden) umur peternak berkisar antara 41-50 tahun yang termasuk dalam usia produktif. Kondisi umur seperti ini membuka peluang untuk kemajuan dan penerapan inovasi. Banyaknya peternak dengan usia produktif yang ikut terlibat akan berpengaruh positif dalam menunjang keberhasilan pelaksanaan program kawasan ternak sapi di Kabupaten Aceh Tamiang.

Persentase seluruh responden (20 orang) adalah peternak laki laki sebesar $100 \%$. Hal ini sangat mendukung dalam keberhasilan dalam suatu kegiatan. Perbedaan jenis kelamin dengan ciri masing-masing menjadi gambaran tingkat kesulitan dari pekerjaan yang digeluti seseorang. Adanya perbedaan kekuatan fisik yang dimiliki antara laki-laki dan perempuan biasanya memberikan dampak perbedaan pada hasil kerja mereka. Wahyono [18], melaporkan bahwa penanganan yang tepat dan penempatan posisi kerja yang tepat juga akan meningkatkan efektivitas dan produktivitas sebagai faktor pendukung kesuksesan dari suatu usaha. Mengingat usaha ini membutuhkan tenaga yang lebih besar dalam pemeliharaannnya, tidak menutup kemungkinan jika dalam mengusahakannya laki-laki dan perempuan saling kerjasama.

Berdasarkan Tabel 1, tingkat pendidikan yang rendah akan mempengaruhi motivasi dan partisipasi peternak dalam pelaksanaan program kawasan. Keikutsertaan seseorang dalam suatu kegiatan erat kaitannya dengan pengetahuan, motivasi dan partisipasi. Adanya pengetahuan tentang manfaat melakukan suatu kegiatan menyebabkan orang mempunyai sikap positif terhadap hal tersebut, dan selanjutnya dapat memotivasinya untuk ikut dalam kegiatan itu. Latar belakang pendidikan formal responden yang cukup tinggi diikuti dengan tingkat pengetahuan responden merupakan salah satu faktor penunjang bagi responden untuk memahami mengenai pola kemitraan dan cara pemeliharaan [19]. Pendidikan merupakan salah satu syarat penunjang berhasil tidaknya beternak, karena pendidikan juga berpengaruh pada cara berpikir dalam mengambil keputusan.

Beternak memang menjadi pekerjaan utama dari peserta kajian. Semua peserta kelompok masuk kategori peternak. Intinya, sesuai dengan tuntutan awal kriteria peternak kajian sudah terpenuhi yaitu peternak memang memiliki kebun sawit sekaligus memelihara ternak sapi. Bertambahnya 
tingkat pengalaman diharapkan agar peternak lebih dinamis, aktif, dan terbuka dalam mengadopsi teknologi baru di Kabupaten Aceh Tamiang. Lebih jauh diungkapkan, seseorang yang mempunyai pengalaman lebih lama akan lebih cepat tanggap dalam pengambilan keputusan, karena pengalaman merupakan pedoman dalam kegiatan usahanya. Hal ini disebabkan peternak khususnya ternak sapi merupakan usaha pokok bagi petani responden [20]. Hal ini menunjukkan pengalaman beternak sapi sudah cukup baik dan akan memberikan pengaruh positif terhadap pengembangan usaha ternak sapi dan penerimaan inovasi dari luar karena didukung dengan usia peternak rata-rata masih produktif.

Hal ini sesuai dengan penelitian Idris et al. [21] bahwa pengalaman beternak dipengaruhi minat, semakin lama pengalaman peternak dalam beternak, maka semakin tinggi minat untuk mengembangkan usahanya. Hal ini dibuktikan dari keterampilan peternak dalam memelihara sapi telah didapatkan sejak kecil karena merupakan usaha turun-temurun [22]. Pengalaman mempengaruhi tingkat pengetahuan peternak terhadap suatu masalah yang dihadapi.

Sistem pemeliharaan ternak semi intensif merupakan sistem pemeliharaan sapi potong dengan sebagian pemeliharaannya digembalakan dan sebagian lagi dikandangkan. Sistem pemeliharaan yang dilaksanakan peternak tidak lepas dari kondisi sosial ekonomi peternak. Pemberian pakan yang diberikan pada ternak diusahakan mengandung zat-zat pakan yang dibutuhkan ternak untuk memenuhi kebutuhan hidup pokok, pertumbuhan, dan reproduksi. Persentase pemberian pakan hijauan, konsentrat, suplemen mineral diberikan secara teratur sesuai dengan perlakuan kajian sebesar 100\%. Hal ini menunjukan peternak telah mengadopsi inovasi teknologi yang diberikan. Ketersediaan pakan di lokasi sangat banyak sehingga metode pemberian pakan sapi dilepaskan di umbaran dan sore hari ternak dikandangkan dengan memberi kembali pakan perlakuan. Pengolahan pakan ternak dapat membantu pemenuhan gizi yang dibutuhkan ternak disaat ketersediaan kualitas pakan yang buruk. Masukan teknologi pengolahan pakan dapat diaplikasikan dalam melakukan usaha peternakan oleh seluruh responden yang terdapat di Kabupaten Aceh Tamiang terbukti dengan meratanya penyuluhan yang dilakukan pada saat kajian berlangsung. Kesulitan dalam menyediakan pakan secara berkesinambungan, baik jumlah maupun kualitasnya, dapat menurunkan produktivitas ternak.

Kariyasa [7], menambahkan bahwa model integrasi tanaman-ternak dapat mengatasi masalah ketersediaan pakan. Ternak dapat memanfaatkan limbah tanaman pertanian dan perkebunan terutama pada musim kemarau. Pemanfaatan limbah dapat menghemat tenaga kerja untuk menyediakan pakan (rumput), sehingga memberi peluang

Tabel 4. Total penerimaan dari pertambahan bobot badan selama penelitian

\begin{tabular}{cccc}
\hline Perlakuan & Berat Badan Akhir $(\mathrm{kg})$ & Harga Sapi Per Kg (Bobot Hidup) & Penerimaan \\
\hline P1 & 246,4 & 50.000 & 12.320 .000 \\
P2 & 259 & 50.000 & 12.950 .000 \\
P3 & 262,8 & 50.000 & 13.140 .000 \\
\hline
\end{tabular}

Sumber: Data primer diolah, 2018. 
bagi peternak untuk meningkatkan jumlah ternak yang dipelihara [23].

Dalam menunjang pelaksanaan program pengembangan kawasan sapi lokal Kecamatan Karang Baru memiliki fasilitas pendukung, yaitu Unit Pelaksanaan Tugas Daerah (UPTD) yang berfungsi sebagai pelaksana, pengawasan, pelayanan, dan penanggungjawab pengembangan kawasan peternakan termasuk kawasan sapi potong. Satuan Pelayanan Inseminasi Buatan (IB) yang berfungsi sebagai pelaksana IB dalam meningkatkan reproduktivitas ternak ruminansia seperti pengobatan dan pemberian vitamin yang berfungsi untuk menjaga kondisi ternak. Berdasarkan hasil wawancara kepada responden, pelayanan IB dapat berhasil di lokasi disebabkan adanya program SIWAB yang memberikan pelayanan dan fasilitas gratis kepada peternak di Kabupaten Aceh Tamiang.

Pelayanan peternakan yang masih diterima oleh petani ternak di kawasan sapi lokal berupa pelayanan kesehatan dan penyakit hewan dan penyuluhan, sedangkan pelatihan teknis hanya diterima pada saat awal program berjalan. Pelayanan kesehatan ternak pada awal program berjalan dengan baik. Untuk meningkatkan kompetensi kewirausahaan peternak, program pelatihan perlu dirancang dan diberikan. Pelatihan teknis yang dilakukan pada saat kajian berlangsung meliputi: manajemen kesehatan ternak, pembuatan silase jagung, cara persemaian dan panen indigofera dan pembuatan mineral blok sebagai suplemen untuk ternak sapi. Pelepah kelapa sawit yang digunakan sebagai bahan pakan subtitusi rumput divariasikan pemberiannya sebesar 30-60 \% [24].

Pada Tabel 3 memperlihatkan perbedaan pertambahan berat badan ternak antar perlakuan. Namun demikian, secara umum ternak yang memperoleh suplemen hasil ikutan tanaman sawit mengalami kenaikan berat badan. Sedangkan ternak kontrol mengalami penurunan berat badan. Hal ini diperkuat dengan pernyataan Umar [25], bahwa sapi mampu mengonsumsi pakan berserat tinggi seperti hijauan dan konsentrat dalam jumlah banyak, di mana bahan pakan tersebut dapat disediakan dari limbah tanaman sawit.

Perkembangan usaha sapi potong melahirkan berbagai inovasi yang pada prinsipnya ditujukan untuk mempercepat pertumbuhan dan meningkatkan $\mathrm{PBBH}$ sapi potong. Angka PBBH yang tinggi akan mempercepat waktu pemeliharaan, sehingga sapi dapat dijual lebih cepat dan menguntungkan (Tabel 5). Inovasi yang diberikan biasanya dengan memanipulasi pakan sehingga mampu meningkatkan laju pertumbuhan berat badan [26]. Model pemanfaatan limbah sawit pada ternak sapi secara finansial menguntungkan yang pada akhirnya akan meningkatkan pendapatan petani. Bangun [27] melaporkan pendapatan petani yang menerapkan sistem integrasi sawit-sapi mencapai Rp19.804.571, sedangkan sebelum menerapkan hanya berkisar Rp14.872.181.

Tabel 5. Total pembelian dari bobot badan awal

\begin{tabular}{cccc}
\hline Perlakuan & Berat Badan Awal $(\mathrm{kg})$ & Harga Sapi Per Kg (Bobot Hidup) & Penerimaan \\
\hline P1 & 221 & 50.000 & 11.050 .000 \\
P2 & 218 & 50.000 & 10.900 .000 \\
P3 & 226 & 50.000 & 11.300 .000 \\
\hline
\end{tabular}

Sumber: Data primer diolah, 2018. 


\section{KESIMPULAN}

Hasil kajian membuktikan bahwa ada peluang pemanfaatan hasil ikutan tanaman sawit pakan untuk mempercepat proses adopsi berdasarkan kondisi geografis dan agrofisik wilayah, karakteristik peternak serta aspek pemberian pakan dan layanan peternakan di Kabupaten Aceh Tamiang.

\section{DAFTAR PUSTAKA}

1. Fauziyah, D., R. Nurmalina, and Burhanuddin. 2015. Pengaruh karakteristik peternak melalui kompetensi peternak terhadap kinerja usaha ternak sapi potong di Kabupaten Bandung. Jurnal Agribisnis Indonesia 3:83-96. doi:10.29244/jai.2015.3.2.83-96.

2. Hastang. and A. Asnawi. 2009. Analisis keuntungan peternak sapi potong berbasis peternakan rakyat di Kabupaten Bone. Jurnal Ilmu-Ilmu Peternakan. 1:240-252. doi:10.24252/jiip.v1i3.1548.

3. Priyanto, D. 2011. Strategi pengembangan ternak sapi dan kerbau dalam mendukung PSDS Tahun 2014. J. Litbang. Pertan. Balitnak, Bogor. 30:108-116. doi:10.21082/jp3.v30n3.2011.p108-116.

4. Prawira, H. Y., Muhtarudin and R. Sutrisna. 2015. Potensi pengembangan peternakan sapi potong di Kecamatan Tanjung Bintang Kabupaten Lampung Selatan. Jurnal Ilmiah Peternakan Terpadu. 3:250-255. doi:10.23960/jipt. v3i4. $\mathrm{p} \% 25 \mathrm{p}$.

5. Direktorat Pangan dan Pertanian. 2013. Studi pendahuluan: Rencana pembangunan jangka menengah nasional (RPJMN) bidang pangan dan pertanian 2015-2019. Badan Perencanaan Pembangunan Nasional (BAPPENAS), Jakarta.

6. Ananta, A., H. Hafid, and L. O. A. Sani. 2015. Faktor-faktor yang mempengaruhi produktivitas usaha ternak Sapi Bali pada peternak transmigran dan non transmigran di Pulau Kabaena Kabupaten Bombana. Jurnal Ilmu dan Teknologi Peternakan Tropis. 2:52-67. doi: 10.33772/jitro.v2i3.
7. Kariyasa, K. 2005. Sistem integrasi tanaman ternak dalam perspektif reorientasi kebijakan subsidi pupuk dan peningkatan pendapatan petani. Jurnal Analisis Kebijakan Pertanian. 3:68-80. doi:10.21082/akp.v3n1.2005.68-80.

8. Gordeyase, I. K. M., R. Hartanto, and W. D. Pratiwi. 2006. Proyeksi daya dukung pakan limbah tanaman pangan untuk ternak ruminansia di Jawa Tengah. J. Indonesian Trop. Anim. Agric. 32:285-292.

9. Suwiti, N. K., I. N. K. Besung, N. L. P. Sriyani, and P. Sampurna, 2016. Aplikasi teknologi pada peternakan sapi Bali dengan sistem pemeliharaan berbasis terintegrasi lingkungan. Jurnal Udayana Mengabdi. 15:216-222.

10. Mathius, I. W. 2008. Pengembangan sapi potong berbasis industri kelapa sawit. Pengembangan Inovasi Pertanian. 1:206-224. doi:10.21082/jp3.v31n4.2012. $\mathrm{p} \% 25 \mathrm{p}$.

11. Diwyanto, K. and A. Priyanti. 2009. Pengembangan industri peternakan berbasis sumber daya lokal. Pengembangan Inovasi Pertanian. 2:208-228.

12. Bamualim, A. M., F. Madaris Y. Pendra, E. Mawardi, and Asmak. 2015. Kajian inovasi integrasi tanaman-ternak melalui pemanfaatan hasil ikutan tanaman sawit untuk meningkatkan produksi sapi lokal Sumatera Barat. Jurnal Peternakan Indonesia. 17:83-93. doi:10.25077/jpi.17.2.83-93.2015.

13. Utomo, B.N. dan E. Widjaja. 2012. Pengembangan sapi potong berbasis industri perkebunan kelapa sawit. J. Litbang Pert. 31(4): 153-161.

14. Darmawi, D. 2011. Pendapatan usaha pemeliharaan sapi Bali di Kabupaten Muaro Jambi. Jurnal Ilmiah Ilmu-Ilmu Peternakan. 14:14-22. doi:10.22437/jiiip.v0i0.583.

15. Tumober, J. C., A. Makalew, A. H. S. Salendu, and E. K. M. Endoh. 2014. Analisis keuntungan pemeliharaan ternak sapi di Kecamatan Suluun Tareran Kabupaten Minahasa Selatan. Zootek. 34:18-26. doi:10.35792/zot.34.2.2014.5523.

16. Salman, D. M. and K. Badr. 2011. Linking 
entrepreneurship and total factor productivity what are the economic setting required. Pros. Sem. Intern. Politics \& Eco. Dev. Turki: EFR. p. 98-103.

17. Chamdi, A. N. 2003. Kajian profil sosial ekonomi usaha kambing di Kecamatan Kradenan Kabupaten Grobogan. Pros. Semnas. Tek. Pet. \& Vet. p. 312-315.

18. Wahyono. 2013. Gender dan keluarga: konsep dan realita di Indonesia. Cet ke-1. IPB Press, Bogor.

19. Sulistyati, M., Hermawan, and A, Fitriani. 2013. Potensi usaha peternakan sapi perah rakyat dalam menghadapi pasar global. Jurnal Ilmu Ternak. 13:17-23. doi:10.24198/jit.v13i1.5116.

20. Otoluwa, M. A., A. H. S. Salendu, A. K. Rintjap, and M. T. Massie. 2016. Prospek pengembangan usaha ternak sapi potong di Kecamatan Bolangitang Timur Kabupaten Bolaang Mongondow Utara. Zootek. 36:191-197. doi:10.35792/zot.36.1.2016.10469.

21. Idris, N., H. Afriani, and Fatati. 2009. Minat peternak untuk mengembangkan ternak sapi di kawasan perkebunan kelapa sawit (Studi Kasus: Kecamatan Sungai Bahar Kabupaten Muaro Jambi). Jurnal Penelitian Universitas Jambi Seri Humaniora. 11:1-10.

22. Utami, L. S., S. Baba, and S. N. Sirajuddin. 2016. Hubungan karakteristik peternak dengan skala usaha ternak kerbau di Desa Sumbang Kecamatan Curio Kabupaten Enrekang. Jurnal Ilmu dan Teknologi Peternakan. 4:146-150.

23. Suryana. 2009. Pengembangan usaha ternak sapi potong berorientasi agribisnis dengan pola kemitraan. J. Litbang. Pert. 28:29-37.

24. Elisabeth, J. and S. P. Ginting. 2003. Pemanfaatan hasil samping industri kelapa sawit sebagai bahan pakan ternak sapi potong. Pros. Lok. Nas. Sistem Integrasi Kelapa Sawit-Sapi. p. 110-119.

25. Umar, S. 2009. Potensi perkebunan kelapa sawit sebagai pusat pengembangan sapi potong dalam merevitalisasi dan mengakselerasi pembangunan peternakan berkelanjutan. Pidato Pengukuhan Jabatan Guru Besar Tetap dalam Bidang Ilmu Reproduksi Ternak pada Fakultas
Pertanian Universitas Sumatera Utara, Medan.

26. Sundari, A. S. Rejeki, and H. Triatmaja. 2009. Analisis pendapatan peternak sapi potong sistem pemeliharaan intensif dan konvensional di Kabupaten Sleman Yogyakarta. Si. Pet. 7:73-79. doi:10.20961/sainspet.v7i2.1080.

27. Bangun, R. 2010. Pengembangan sistem integrasi sapi-kebun kelapa sawit dalam peningkatan pendapatan petani di Provinsi Riau. Jurnal Teroka. 10:161-174. 